\title{
Improvement of Cytomegalovirus-Related Guillain-Barré Syndrome after High Doses of Intravenous Methylprednisolone Pulses
}

\author{
Katell Beauvais Alain Furby \\ Unité de Neurophysiologie Clinique, Hôpital Yves Le Foll, Saint-Brieuc, France
}

Dear Sir,

Guillain-Barré syndrome (GBS) is an acute polyradiculoneuropathy, preceded by a cytomegalovirus (CMV) infection in about $10-15 \%$ of cases $[1,2]$. Randomized therapeutic trials on GBS patients have shown that intravenous immunoglobulin (IVIg) and plasma exchange are equally effective [3, 4]. Despite some rare favourable results in open studies $[5,6]$, controlled trials did not prove that oral or intravenous corticoids modify the long-term outcome when given alone in this condition [7].

Here we describe the case of a young woman with GBS preceded by CMV infection who dramatically improved after steroid pulse therapy.

\section{Case Report}

A 24-year-old woman had experienced headache, distal paraesthesiae and progressive muscle weakness of the limbs for a week when she was admitted to hospital. Clinical examination revealed a moderate muscle weakness predominant in the lower limbs and the absence of deep tendon reflexes. The weakness extended rapidly in a few days, with bulbar dysfunction, left facial palsy and difficulty in breathing (fig. 1).

Routine laboratory studies showed hepatic cytolytic and cholestatic abnormali-

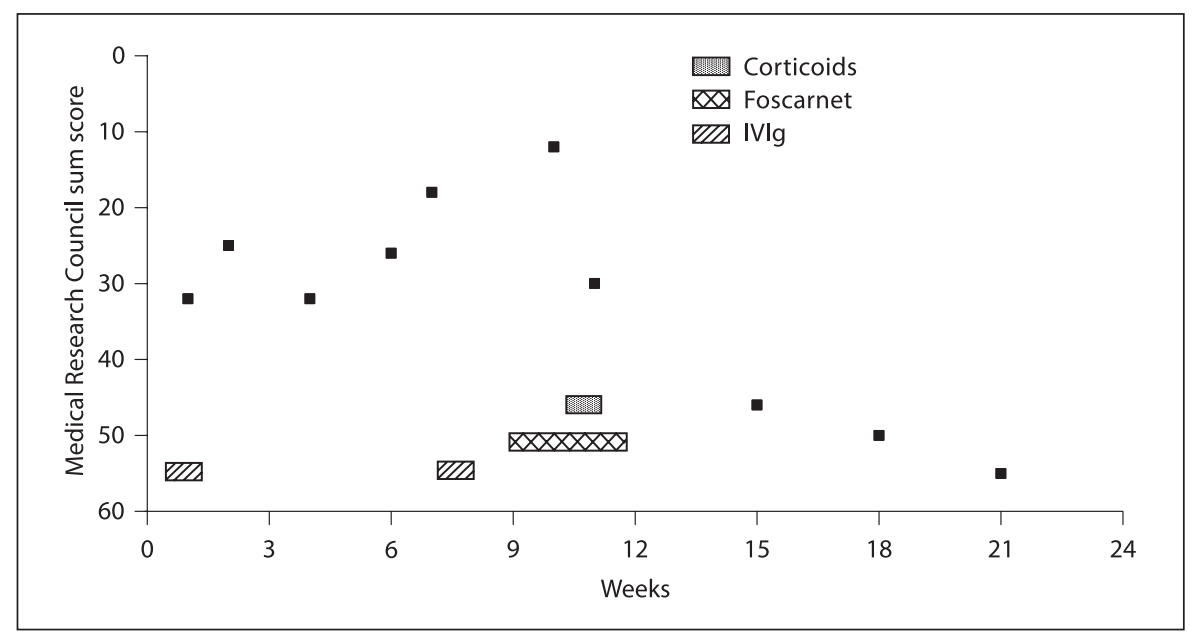

Fig. 1. Clinical and therapeutic data over 5 months.

ties. Cerebrospinal fluid (CSF) examination revealed protein $1.8 \mathrm{~g} / \mathrm{l}$ and a normal leucocyte count. Tests for antiganglioside antibodies and serological studies were negative, except antibodies against CMV (IgM: $6.6 \mathrm{IU} / \mathrm{ml}$, normal value $<1.2 \mathrm{IU} / \mathrm{ml}$; negative $\operatorname{IgG}$ ).

Nerve conduction studies showed prolonged distal motor latencies, absence of $\mathrm{F}$ waves, reduction of nerve conduction ve- locities and multiple motor nerve conduction blocks (table 1). GBS was diagnosed based on the above-mentioned findings, and the patient received IVIg at a dose of $0.4 \mathrm{mg} / \mathrm{kg}$ of body weight per day for 5 days. She slightly improved but the weakness in the upper and lower limbs persisted. Seven weeks after the onset her neurological condition was exacerbated with severe tetraparesis predominant in the lower

\section{KARGER}

Fax +4161306 1234 E-Mail karger@karger.ch www.karger.com
(C) 2006 S. Karger AG, Basel 0014-3022/06/0561-0041\$23.50/0

Accessible online at: www.karger.com/ene
A. Furby

Unité de Neurophysiologie Clinique

Hôpital Yves Le Foll

FR-22023 Saint-Brieuc (France)

Tel. +33 2960171 93, Fax +332960175 03, E-Mail alain.furby@ch-stbrieuc.fr 
Table 1. Time course of electrophysiological results (right/left)

\begin{tabular}{|c|c|c|c|c|}
\hline & $\begin{array}{l}\text { ENMG } 1 \\
\text { day } 8\end{array}$ & $\begin{array}{l}\text { ENMG } 2 \\
\text { month } 2\end{array}$ & $\begin{array}{l}\text { ENMG } 3 \\
\text { month } 5\end{array}$ & $\begin{array}{l}\text { Normal } \\
\text { limit }\end{array}$ \\
\hline \multicolumn{5}{|l|}{ Median CMAP } \\
\hline $\mathrm{DL}, \mathrm{ms}$ & $5.7 / 5.9$ & $30 / 26.2$ & $13 / 11$ & $<4$ \\
\hline $\mathrm{NCV}, \mathrm{m} / \mathrm{s}$ & $32 / 41$ & $11 / 13$ & $24 / 29$ & $>50$ \\
\hline Dist. amp., mV & $3.1 / 3.8$ & $0.3 / 0.8$ & $1 / 1.8$ & $>3.5$ \\
\hline Prox. amp., mV & $0.8 / 2.4$ & $0.07 / 0.08$ & $1 / 1.5$ & $>3.5$ \\
\hline \multicolumn{5}{|l|}{ Ulnar CMAP } \\
\hline $\mathrm{DL}, \mathrm{ms}$ & $\mathrm{ND} / \mathrm{ND}$ & 0/ND & $5.6 / 6.4$ & $<3$ \\
\hline $\mathrm{NCV}, \mathrm{m} / \mathrm{s}$ & $\mathrm{ND} / \mathrm{ND}$ & NR/ND & $7 / 21$ & $>50$ \\
\hline Dist. amp., mV & $\mathrm{ND} / \mathrm{ND}$ & $0.04 / \mathrm{ND}$ & $0.5 / 0.6$ & $>2.8$ \\
\hline Prox. amp., mV & $\mathrm{ND} / \mathrm{ND}$ & NR/ND & $0.3 / 0.6$ & $>2.8$ \\
\hline \multicolumn{5}{|l|}{ Peroneal CMAP } \\
\hline $\mathrm{DL}, \mathrm{ms}$ & $5.7 / 5.5$ & NR/NR & $9.1 / 14.8$ & $<5.5$ \\
\hline $\mathrm{NCV}, \mathrm{m} / \mathrm{s}$ & $29 / 23$ & NR/NR & $15 / 14$ & $>40$ \\
\hline Dist. amp., mV & $2.4 / 3$ & NR/NR & $1.6 / 1.9$ & $>2.5$ \\
\hline Prox. amp., mV & $0.8 / 0.4$ & NR/NR & $1.2 / 1.6$ & $>2.5$ \\
\hline \multicolumn{5}{|l|}{ Sural SNAP } \\
\hline $\mathrm{NCV}, \mathrm{m} / \mathrm{s}$ & $45 / 12$ & NR/NR & NR/NR & $>40$ \\
\hline Amp., $\mu \mathrm{V}$ & $40 / 20.5$ & NR/NR & NR/NR & $>8$ \\
\hline \multicolumn{5}{|l|}{ Ulnar SNAP } \\
\hline $\mathrm{NCV}, \mathrm{m} / \mathrm{s}$ & NR/50 & NR/NR & NR/NR & $>45$ \\
\hline Amp., $\mu \mathrm{V}$ & $\mathrm{NR} / 1.5$ & NR/NR & NR/NR & $>5$ \\
\hline \multicolumn{5}{|l|}{ Median SNAP } \\
\hline $\mathrm{NCV}, \mathrm{m} / \mathrm{s}$ & $\mathrm{NR} / 43$ & NR/NR & NR/NR & $>45$ \\
\hline Amp., $\mu \mathrm{V}$ & $\mathrm{NR} / 1.8$ & NR/NR & NR/NR & $>5$ \\
\hline
\end{tabular}

$\mathrm{ENMG}=$ Electroneuromyography; $\mathrm{NR}=$ no response; $\mathrm{ND}=$ not done $\mathrm{CMAP}=\mathrm{com}$ pound motor action potential; $\mathrm{DL}=$ distal latency; $\mathrm{NCV}=$ nerve conduction velocity; amp. $=$ amplitude (negative peak); SNAP = sensory nerve action potential; dist. $=$ distal; prox. $=$ proximal.

limbs, bilateral facial palsy, diffuse hypoaesthesia and bladder dysfunction (fig. 1). At this time, electroneuromyography displayed persisting conduction blocks and severe axonal loss (table 1). CSF protein was $5.6 \mathrm{~g} / \mathrm{l}$ with 14 leucocytes. Cerebral MRI was normal. Serum IgM and IgG CMV antibodies were increased (IgG: $2.63 \mathrm{IU} / \mathrm{ml}$, normal value $<0.4 \mathrm{IU} / \mathrm{ml}$; IgM: $2 \mathrm{IU} / \mathrm{ml})$. Neither a second dose of IVIg nor foscarnet were effective. Three weeks after the exacerbation, she received $1 \mathrm{~g} /$ day of methylprednisolone intravenously for 5 days and rapidly improved within a week (fig. 1). The recovery started in the pelvic and scapular girdles. Electroneuromyography 3 months later was also notably improved but still showed distal axonal loss predominant in the lower limbs (table 1). The outcome after 1 year was excellent: the patient only retained some paraesthesiae in the extremities and suffered no relapse 32 months later.

\section{Discussion}

The first presentation of our patient fulfilled the clinical, electrophysiological and CSF criteria for acute GBS [8]. However, despite initial improvement after IVIg, her condition worsened 7 weeks after onset. Since the time to reach the nadir in GBS is normally within 4 weeks, this case could be considered as acute chronic inflammatory demyelinating polyneuropathy (acute CIDP) or subacute inflammatory demyelinating polyneuropathy
(SIDP). However, several arguments contradict either hypothesis: (1) according to the study of Ruts et al. [9], the diagnosis of acute CIDP should be considered when the deterioration occurs after 9 weeks from onset; (2) our patient had a rapid severe course within 2 weeks, which is not consistent with cases of SIDP reported by Oh et al. [10]; (3) she had no relapse on a followup longer than 2 years. So, this patient may rather be diagnosed as a case of GBS with treatment-related fluctuations [9]. Moreover, she had the characteristic clinical and electrophysiological pattern of CMVrelated GBS described by Visser et al. [2] and Ogawara et al. [11] in that she was young and experienced a severe course, with sensory and motor pattern of four limbs, cranial nerve involvement, respiratory insufficiency and demyelination on nerve conduction studies. Benefits of antiviral treatment have been reported in this condition [12]. We cannot exclude a delayed effect of foscarnet in our patient, but she continued to worsen 2 weeks after initiating this treatment. A second dose of IVIg was ineffective as well. In fact, a clear improvement was only observed after steroid pulse therapy. Two open studies actually suggested a beneficial effect of intravenous methylprednisolone in GBS patients $[5,6]$ but none of the published controlled trials supported its use $[3,7,13,14]$. Nevertheless, a recent paper described a favourable outcome in a case of CMV-related GBS after steroid pulse therapy as was the case with our patient [15]. Such cases may sustain the hypothesis that pathogenic mechanisms in CMV-related GBS are in part distinct from classical GBS. Indeed, other factors could explain the efficiency of corticoids such as the timing of their administration. They should be more efficient in the first stage of the disease because of the presence of inflammation. In our patient, the initial recovery in limb girdle muscles was probably due to the persisting inflammatory process and the release of proximal conduction blocks.

In conclusion, high doses of intravenous steroid pulses should be tried in CMV-related GBS when other treatments are ineffective or when clinical worsening occurs after initial improvement or stabilization.

\section{Acknowledgement}

We are grateful to J.F. Vernet for reading the manuscript. 


\section{References}

1 Winer JB, Hughes RA, Anderson MJ, Jones DM, Kangro H, Watkins RP: A prospective study of acute idiopathic neuropathy. II. Antecedent events. J Neurol Neurosurg Psychiatry 1988;51:613-618.

2 Visser LH, van der Meche FG, Meulstee J, Rothbarth PP, Jacobs BC, Schmitz PI, van Doorn PA: Cytomegalovirus infection and Guillain-Barré syndrome: the clinical, electrophysiologic, and prognostic features. Dutch Guillain-Barré Study Group. Neurology 1996;47:668-673.

3 Van der Meche FG, Schmitz PI: A randomized trial comparing intravenous immune globulin and plasma exchange in GuillainBarré syndrome. Dutch Guillain-Barré Study Group. N Engl J Med 1992;326:11231129.

4 Plasma Exchange/Sandoglobulin GuillainBarré Syndrome Trial Group: Randomised trial of plasma exchange, intravenous immunoglobulin, and combined treatments in Guillain-Barré syndrome. Lancet 1997;349: 225-230.
5 Dowling PC, Bosch VV, Cook SD: Possible beneficial effect of high-dose intravenous steroid therapy in acute demyelinating disease and transverse myelitis. Neurology 1980;30:33-36.

6 Haass A, Trabert W, Gressnich N, Schimrigk $\mathrm{K}$ : High-dose steroid therapy in GuillainBarré syndrome. J Neuroimmunol 1988;20: 305-308.

7 Guillain-Barré Syndrome Steroid Trial Group: Double-blind trial of intravenous methylprednisolone in Guillain-Barré syndrome. Lancet 1993;341:586-590.

8 Asbury AK, Cornblath DR: Assessment of current diagnostic criteria for Guillain-Barré syndrome. Ann Neurol 1990;27(suppl): S21-S24.

9 Ruts L, van Koningsveld R, van Doorn PA: Distinguishing acute-onset CIDP from Guillain-Barré syndrome with treatment related fluctuations. Neurology 2005;65:138-140.

10 Oh SJ, Kurokawa K, de Almeida DF, Ryan HF Jr, Claussen GC: Subacute inflammatory demyelinating polyneuropathy. Neurology 2003;61:1507-1512.

11 Ogawara K, Kuwabara S, Mori M, Hattori T, Koga M, Yuki N: Axonal Guillain-Barré syndrome: relation to anti-ganglioside antibodies and Campylobacter jejuni infection in Japan. Ann Neurol 2000;48:624-631.
12 Steininger C, Popow-Kraupp T, Seiser A, Gueler N, Stanek G, Puchhammer E: Presence of cytomegalovirus in cerebrospinal fluid of patients with Guillain-Barré syndrome. J Infect Dis 2004;189:984-989.

13 Hughes RA, Van der Meche FG: Corticosteroids for Guillain-Barré syndrome (update). Cochrane Database Syst Rev2005;2: CD001446.

14 Van Koningsveld GA, Schmitz PI, van der Meche F, Visser LH, Meulstee J, van Doorn PA, for the Dutch Guillain-Barré Syndrome Study Group: Effect of methylprednisolone when added to standard treatment with intravenous immunoglobulin for GuillainBarré syndrome: randomized trial. Lancet 2004;363:192-196.

15 Tada M, Onodera O, Kawachi I, Hara K, Sato M, Yoshino H, Asano A, Soma Y, Tsuji S: Steroid-pulse therapy in Guillain-Barré syndrome associated with cytomegalovirus infection: a case report. No To Shinkei 2003;55: 615-621. 